\title{
Physico Chemical Monitoring Tests of Geothermal Water Production Wells
}

\author{
MIOARA SEBESAN ${ }^{1}$, GABRIELA ELENA BADEA ${ }^{1}$, RADU SEBESAN², ILONA KATALIN FODOR ${ }^{3 *}$, SIMONA BUNGAU3*, \\ SIMONA TICU (COTORCEA) ${ }^{4}$ \\ 'University of Oradea, Faculty of Sciences, 1 Universitatii St., 410087, Oradea, Romania \\ ¿University of Oradea, Faculty of Electrical Engineering and Information Technology, 1 Universitatii Str., 410087, Oradea, Romania \\ 'University of Oradea, Faculty of Medicine and Pharmacy, 29 Nicolae Jiga Str., 410028, Oradea, Romania \\ 4Politehnica University of Bucharest, Faculty of Applied Chemistry and Materials Science, 1-7 Gh. P. Polizu Str., 011061, Bucharest, \\ Romania
}

This paper presents a study of the physico-chemical properties of geothermal fluids, coming from some wells in Sacuieni, Bihor County, Romania. The thermal energy of the geothermal waters studied is used for heating some industrial buildings, greenhouses, and administrative buildings. Continuous monitoring of physical and chemical characteristics of geothermal waters is needed. Based on this fact, a classification of these waters has been made according to their chemical composition. Using a silica-enthalpy thermodynamic model, it was possible to estimate the deep reservoir temperature, and compare it with the temperatures at depth, calculated by the silica (quartz and chalcedony) and $\mathrm{Na}+/ \mathrm{K}+$ geothermometers. The WATCH program is used to estimate the mineral deposits that may accumulate due to boiling and cooling of the geothermal fluid when it is used in heat exchangers The results are confirmed by XRD spectrometric and thermogravimetric analyses.

Keywords: geothermal water, geothermometers, silica-enthalpy model, X-Ray diffraction

Geothermal systems are present in nature in many combinations of physical, chemical and geological characteristics, which are reflected in geothermal fluids properties and their potential industrial applications. An important task in the geothermal resource utilization is to estimate the reservoir temperature using geochemical studies.

Underground temperatures are estimated using chemical geothermometers. However, the deep temperatures could be underestimated because of the lateral flow of meteoric water and these differences are explained by the slow equilibrium attainment rate of geothermometers reaction [1].

In the last few decades many researchers developed geochemical geothermometers, which could have been used for different hydrogeological conditions. In this area scientists have carried out many studies on geothermal waters [2-13], regarding: geochemistry [2-5,7,8,13], geothermometry $[2-7,11,13]$, mineral saturation $[5,7]$, geochemical modeling $[5,8,12]$ and $\mathrm{X}$-ray diffraction measurements $[9,10]$.

Geothermal water utilization in Romania [14] is based on direct use or through heat exchanger, when heated water is used as tap water in greenhouses, swimming pools and for technological purposes. Even if there are many domestic and industrial applications of geothermal water utilization, there is not too much published information on geothermal potential in the Western Plain of Romania.

Through analysis of all hydrogeological data and by tracking the results of production parameters there was found that a phenomenon frequently encountered during exploitation of geothermal water is the formation of the upper crust in the distribution pipes and on the heat exchanger surfaces.

The geothermal unit Sacuieni is part of tectonic depression Mountain Sannicolau, located on the western edge of the Pannonian Basin found in crystalline formation, at depths between 2100 and $2500 \mathrm{~m}$. Further studies on chemical composition of geothermal waters of different wells in Pannonian Basin proved the possibility of their using, coming to complete the whole view on the main chemical characteristics of the reservoir [21-23]. By monitoring the chemical composition of the geothermal systems, the deposit and corrosion problems can be estimated, avoiding their occurrence by taking the right measures, in order to smartly use their potential in various urban and industrial energy applications [24-33] .

Sacuieni geothermal aquifer, a less studied area regarding the physico-chemical characteristics, but important from the economical point of view, being exploited for heating of industrial and administrative buildings, was observed in this study. Water samples from two geothermal production wells, 4076 and 4057 were analyzed for their major ions composition.

This paper presents a study of the physico-chemical monitoring of these two wells from Sacuieni, using modeling programs based on composition of these waters, in order to get useful determinations for efficient operation of geothermal fluid energy.

\section{Experimental part}

Sampling methods were applied according to the specific methodology used for geothermal fluids and the physico-chemical analysis were performed by standard accurate methods, so that the results could be used for interpretation. Analysis for sodium, potassium, calcium, magnesium and iron were carried out by atomic absorption spectroscopy, using a VARIAN SPECTRA AA 110 spectrophotometer. For silica analysis was applied a UV-Vis spectrophotometric method, by using a CARRY 50 spectrophotometer. Ammonia was colorimetrically determined. Carbon dioxide was determined by titration

*email: katifodor@yahoo.com; simonabungau@gmail.com,

All the authors have equal contribution at this original article. Phone +40726776588 
with hydrochloric acid solution in the presence of methyl orange. The method is based on neutralization of carbonates with hydrochloric acid to bicarbonate stage, using phenolphthalein as indicator. Chloride was analyzed by titration with silver nitrate solution in the presence of potassium chromate as indicator (Mohr method). Sulfate was analyzed by titration with barium perchlorate solution using Thorin as indicator. $\mathrm{H}_{2} \mathrm{~S}$ determination was performed by titration with mercuric acetate in the presence of dithizone as indicator.

Scale formation has been of great concern in exploitation of geothermal resources, as scale interfere with the production capacities of wells by clogging either the boreholes or the pipes. Estimating the occurrence of solid phases which could precipitate depending on the temperature and the chemical characteristics of geothermal waters is necessary. Because of the extent of geothermal waters use, their temperatures decrease. This influences the mineral solubility. An important application of Watch program is to determine the solubility product, assuming a conductive cooling in several steps. Working with the chemical composition, the Watch program [34] allows to calculate the corresponding solubility product, Q, and compare it with theoretical solubility product, $\mathrm{K}$, for different minerals. When $\mathrm{Q}<\mathrm{K}$ the saturation index is negative and the solution under-saturated regarding the mineral considered. When $\mathrm{Q}>\mathrm{K}$ the solution is supersaturated and when $Q=K$ the solution is exactly saturated or in equilibrium with the mineral considered.

Solid samples of mineral deposits taken from plate exchangers when they had been cleaned, were structurally analyzed by thermo-differential analysis and by X-ray analysis. For thermal and thermo-differential analysis of the solid samples, a Q-1500D derivatograph was used $[6,7]$. Thermal regime selected was $20 \%$ min to $1000^{\circ} \mathrm{C}$. Recorder sensitivity was: the TG $-500 \mu \mathrm{V}$, the

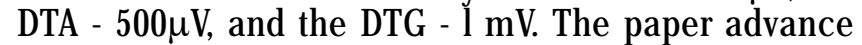
speed was $5 \mathrm{~mm} /$ minute. The X-ray analysis were done with a PHILIPS PW 1400 X-ray spectrometer using $\mathrm{K} \alpha \mathrm{Cu}$ radiation, at chamber temperature, resulting in information on existing crystals in the solid samples.

\section{Results and discussions}

Experimental data on the chemical composition of geothermal water taken in the study are presented in Table 1 .

\begin{tabular}{|c|c|c|}
\hline \multirow{2}{*}{ Chemical characteristics } & \multicolumn{2}{|c|}{ Wells } \\
\cline { 2 - 3 } & 4057 & 4076 \\
\hline $\mathrm{pH}$ & 7.2 & 8.2 \\
\hline $\mathrm{Na}^{+}$ & 1314 & 1120 \\
\hline $\mathrm{K}^{+}$ & 104 & 108 \\
\hline $\mathrm{Ca}^{2+}$ & 12.2 & 10.2 \\
\hline $\mathrm{Mg}^{2+}$ & 0.47 & 0.2 \\
\hline $\mathrm{Cl}^{-}$ & 916 & 566 \\
\hline $\mathrm{SO}_{4}^{2-}$ & 25 & 36 \\
\hline $\mathrm{HCO}_{3}{ }^{-}$ & 2236 & 2330 \\
\hline $\mathrm{SiO}_{2}$ & 51 & 78 \\
\hline $\mathrm{Fe}^{2+}$ & 0.4 & - \\
\hline $\mathrm{CO}_{2}$ & 1900 & 1090 \\
\hline $\mathrm{Mineralization}_{2}$ & 4246 & 4390 \\
\hline $\mathrm{H}_{2} \mathrm{~S}$ & 0.2 & - \\
\hline
\end{tabular}

Table 1

CHEMICAL COMPOSITION OF GEOTHERMAL WATERS (CONCENTRATIONS OF IONS, $\mathrm{mg} / \mathrm{L}$ ) OF 4057 AND 4076 WELLS FROM SACUIENI

An initial classification of the studied waters, in terms of major cations was done by using the $\mathrm{Na}^{+}-\mathrm{K}^{+}-\mathrm{Mg}^{2+}$ ternary diagram [2, 3] (Figure 1).

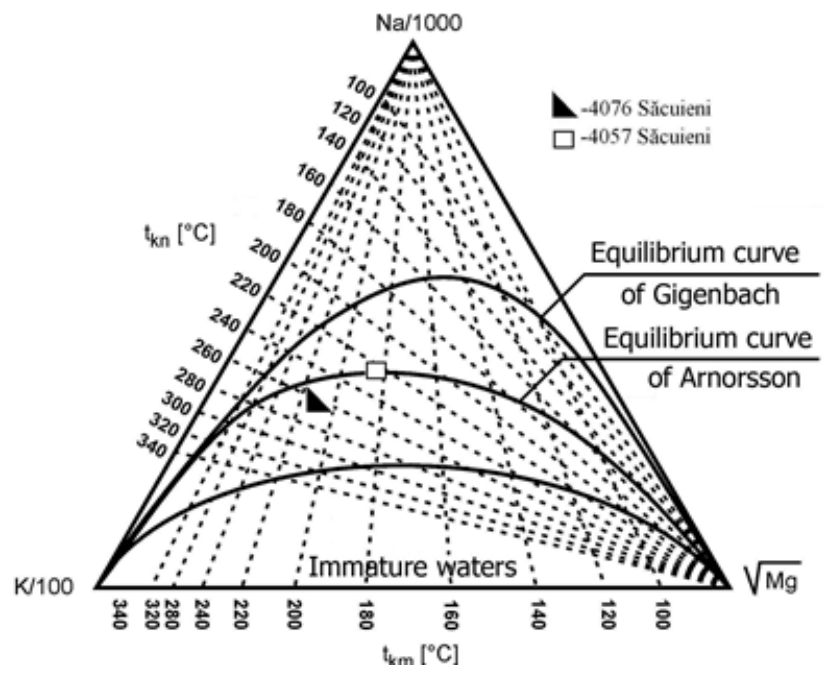

Fig.1. Ternary diagram $\mathrm{Na}^{+}-\mathrm{K}^{+}-\mathrm{Mg}^{2+}$ for geothermal waters from wells: Sacuieni 4076 and Sacuieni 4057

Sodium is the dominant cation in both water samples. Waters from well 4076 plot in the partial equilibration area, being close to Arnorsson's equilibrium curve. This is a good indication that these waters can safely be used for geothermometry calculations. Partial equilibration may be due to reactions with the wall rocks during re-equilibration or could result from mixing. Waters from well 4057 reach the fully equilibrated water curve after Arnorsson.

Another classification of geothermal waters concerning the major anions [1] is illustrated in the triangular diagram $\mathrm{Cl}$; $\mathrm{SO}_{4}^{2-}$ and $\mathrm{HCO}_{3}$, figure 2. Waters from the two wells from Sacuieni fall in the field of peripheral waters. The samples are rich in bicarbonate.

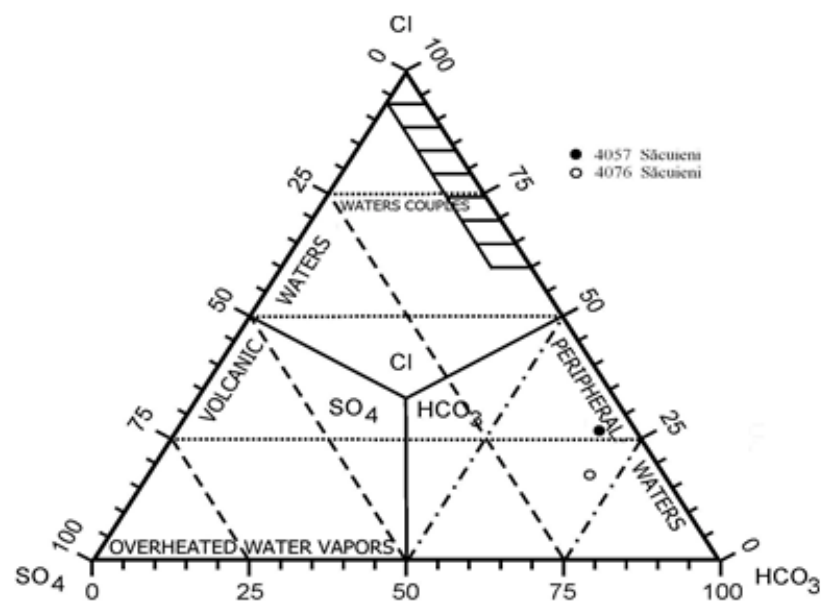

Fig. 2. Ternary diagram $\mathrm{Cl}_{-}-\mathrm{SO}_{4}{ }^{2-}-\mathrm{HCO}_{3}$ - for waters from 4057 and 4076 geothermal wells of Sacuieni

Depth Temperature Estimation of the Geothermal Reservoir

A series of indicators to estimate the temperature of water depth were applied. The use of geothermometers is based on the assumption that there is an equilibrium between the rock minerals and the fluid from the reservoir. The chemical composition of the surface fluid is mainly controlled by rock mineral composition and the deep reservoir temperature. The solubility of some components of the geothermal fluid is controlled by the temperature. The temperatures resulting from calculations with geothermometers by the Watch program are presented in Table 2 
Table 2

TEMPERATURES RESULTED BY WATCH PROGRAM CALCULATIONS

Table 3

TEMPERATURES RESULTED BY SILICA-ENTHALPY MODEL CALCULATIONS

\begin{tabular}{|c|c|c|c|c|c|c|c|}
\hline Well & $\begin{array}{c}\text { Wellhead } \\
\text { temperature }{ }^{\circ} \mathrm{C}\end{array}$ & $\begin{array}{c}\mathrm{T},{ }^{\circ} \mathrm{C} \\
(\mathrm{Quartz})\end{array}$ & $\begin{array}{c}\mathrm{T},{ }^{\circ} \mathrm{C} \\
(\mathrm{Chalcedony})\end{array}$ & $\begin{array}{c}\mathrm{T},{ }^{\circ} \mathrm{C} \\
\left(\mathrm{Na}^{+} / \mathrm{K}^{+}\right)\end{array}$ \\
\hline 4076 & 81 & 80.5 & 87.0 & 263.2 & Well & $\begin{array}{c}\text { SiO } \\
(\mathrm{mg} / \mathrm{L})\end{array}$ & $\begin{array}{c}\text { Enthalpy in } \\
\text { reservoir } \\
(\mathrm{kJ} / \mathrm{kg})\end{array}$ \\
\hline 4057 & 82 & 79.5 & 86.6 & 226.8 & $\begin{array}{c}\mathrm{Hot} \text { water } \\
\text { temperature in } \\
\text { reservoir, }\left({ }^{\circ} \mathrm{C}\right)\end{array}$ \\
\hline 4
\end{tabular}

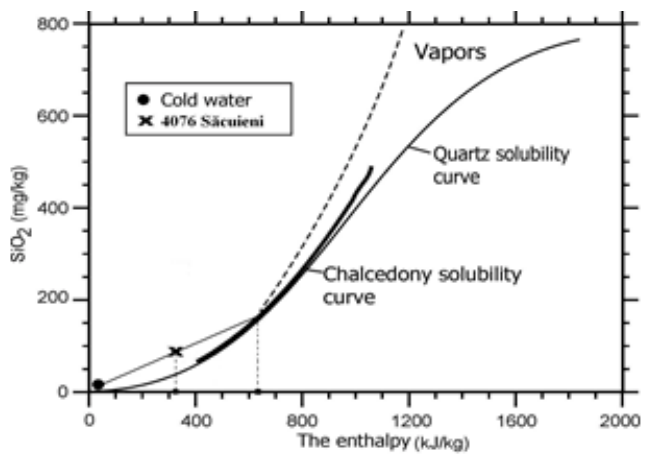

a. Well 4057

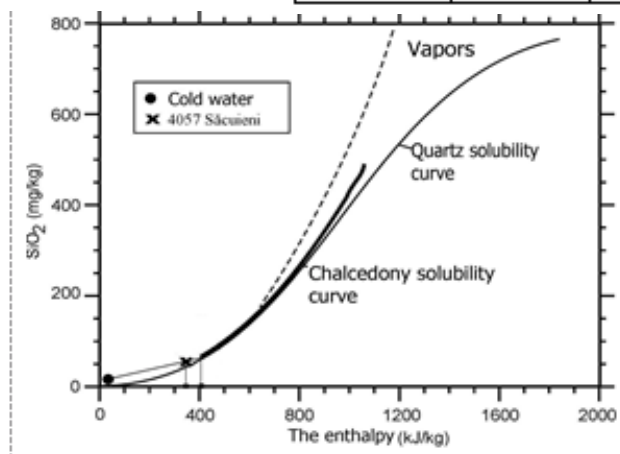

b. Well 4076

Fig.3. Silica-enthalpy model

Silica geothermometers temperatures are closer to the wellhead temperatures than the values given by $\mathrm{Na} / \mathrm{K}$ geothermometer. It seems that quartz geothermometer [5] control better the temperature of silica equilibrium in the reservoir. The $\mathrm{Na} / \mathrm{K}$ geothermometer does not give good results for these low-temperature geothermal waters.

Another way to estimate the geothermal reservoir temperature is by using the silica-enthal py model [4]. It is assumed that the geothermal water at the surface is the result of geothermal hot water mixed with cold water. The diagrams (Figure $3 a$ and $b$ ) plot silica versus the enthalpy of water, giving the temperature of the deep hot water component.

The cold water point was assumed to represent the hypothetical cold ground water of $10^{\circ} \mathrm{C}$ temperature and $20 \mathrm{mg} \mathrm{SiO} / \mathrm{L}$ in the study area. The intersection point of the cold water - geothermal water line with the solubility of chalcedony curve gives the silica content and the enthalpy of the deep hot water component, and its temperature are obtained from the steam tables. Based on this model, a temperature of $151.9^{\circ} \mathrm{C}$ was obtained for the deep geothermal water from well 4076 and $96.43^{\circ} \mathrm{C}$ for deep geothermal water from well 4057.

As a result, it means that there is a mixing of hot geothermal water with cold water from the upper layers, causing the cooling of the water which reaches the surface. The temperatures measured at the wellhead were $81^{\circ} \mathrm{C}$ for waters from geothermal well 4076 and $82^{\circ} \mathrm{C}$ for geothermal water from well 4057 , values close to those calculated by the quartz and chalcedony geothermometers.

The assessment of scaling problems was conducted through the interpretation of analytical data by the use of Watch program, being calculated the log solubility index for different minerals. The data from Watch program are presented in Tables 4 and 5 and illustrated in Figures $4 a$ and $b$.

For the geothermal water from well 4057 from Sacuieni was recorded a supersaturation with anhydrite, quart, and chalcedony at lower temperatures which can be reached in the distribution equipment during geothermal water utilization. Calcite corresponding curve lies above the equilibrium line. It might be expected calcium carbonate deposition at wellhead temperature and also at lower temperatures. There is undersaturation in respect with remaining calculated minerals.

In the sample from well 4076 from Sacuieni quartz, chalcedony and calcite are supersaturated, while other minerals have spread curves below the saturation line, indicating undersaturation in relation to those minerals.

\section{Structural analysis of scales}

From the thermo-differential diagram (Figure 5a) obtained for the solid deposition from well 4057 it can be noticed a decomposition process that starts slowly at about $730^{\circ} \mathrm{C}$ and reaches a maximum at $960^{\circ} \mathrm{C}$. The mass loss is about $44.56 \%$ in the range of temperatures 700 $1000^{\circ} \mathrm{C}$. The thermo-differential analysis of the solid sample

\begin{tabular}{|c|c|c|c|c|}
\hline $\begin{array}{c}\mathrm{T}, \\
{ }^{\circ} \mathrm{C}\end{array}$ & $\begin{array}{c}\text { Log.Q/K } \\
\text { (Anhyd.) }\end{array}$ & $\begin{array}{c}\text { Log.Q/K } \\
\text { (Calcite) }\end{array}$ & $\begin{array}{c}\text { Log.Q/K } \\
\text { (Chalc.) }\end{array}$ & $\begin{array}{c}\text { Log.Q/K } \\
\text { (Quartz) }\end{array}$ \\
\hline 82 & 0.022 & 0.243 & -0.025 & 0.199 \\
\hline 60 & 0.616 & 0.381 & 0.513 & 0.835 \\
\hline 45 & 0.744 & 0.506 & 1.669 & 1.009 \\
\hline 30 & 0.865 & 0.847 & 2.841 & 1.191 \\
\hline \hline${ }^{\circ}$, & $\begin{array}{c}\text { Log.Q/K } \\
\text { (Talc) }\end{array}$ & $\begin{array}{c}\text { Log.Q/K } \\
\text { (Wollast.) }\end{array}$ & $\begin{array}{c}\text { Log.Q/K } \\
\text { (Chrysot) }\end{array}$ & $\begin{array}{c}\text { Log.Q/K } \\
\text { (Amorph. Silica) }\end{array}$ \\
\hline 82 & 4.153 & -2.569 & 0.89 & -0.587 \\
\hline 60 & 2.349 & -4.276 & -1.469 & -0.229 \\
\hline 45 & 2.075 & -5.264 & -1.952 & -0.126 \\
\hline 30 & 1.011 & -5.816 & -2.461 & -0.011 \\
\hline
\end{tabular}

Table 4

VALUES OF SATURATION INDEXES OF MINERALS FROM 4057 WELL IN SACUIENI 


\begin{tabular}{|c|c|c|c|c|}
\hline $\begin{array}{c}\mathrm{T}, \\
{ }^{\circ} \mathrm{C}\end{array}$ & $\begin{array}{c}\text { Log.Q/K } \\
\text { (Anhyd.) }\end{array}$ & $\begin{array}{c}\text { Log.Q/K } \\
\text { (Calcite) }\end{array}$ & $\begin{array}{c}\text { Log.Q/K } \\
\text { (Chalc.) }\end{array}$ & $\begin{array}{c}\text { Log.Q/K } \\
\text { (Quartz) }\end{array}$ \\
\hline 81 & -2.495 & 0.238 & 0.009 & 0.382 \\
\hline 75 & -2.476 & 0.352 & -0.017 & 0.293 \\
\hline 60 & -2.561 & 0.497 & 0.077 & 0.360 \\
\hline 45 & -2.624 & 0.046 & 0.224 & 0.548 \\
\hline 20 & -2.745 & -0.003 & 0.373 & 0.729 \\
\hline \hline $\begin{array}{c}\mathrm{T}, \\
{ }^{\circ} \mathrm{C}\end{array}$ & $\begin{array}{c}\text { Log.Q/K } \\
\text { (Talc) }\end{array}$ & $\begin{array}{c}\text { Log.Q/K } \\
\text { (Wollast.) }\end{array}$ & $\begin{array}{c}\text { Log.Q/K } \\
\text { (Chrysot) }\end{array}$ & $\begin{array}{c}\text { Log.Q/K } \\
\text { (Amorph. Silica) }\end{array}$ \\
\hline 81 & -1.390 & -5.151 & -3.091 & -0.712 \\
\hline 75 & -0.506 & -4.976 & -2.810 & -0.801 \\
\hline 60 & -1.718 & -5.227 & -4.302 & -0.791 \\
\hline 45 & -2.846 & -5.980 & -5.824 & -0.592 \\
\hline 20 & -3.895 & -6.555 & -7.456 & -0.456 \\
\hline
\end{tabular}

Table 5

VALUES OF SATURATION INDEXES OF MINERALS FROM 4076 WELL IN SACUIENI

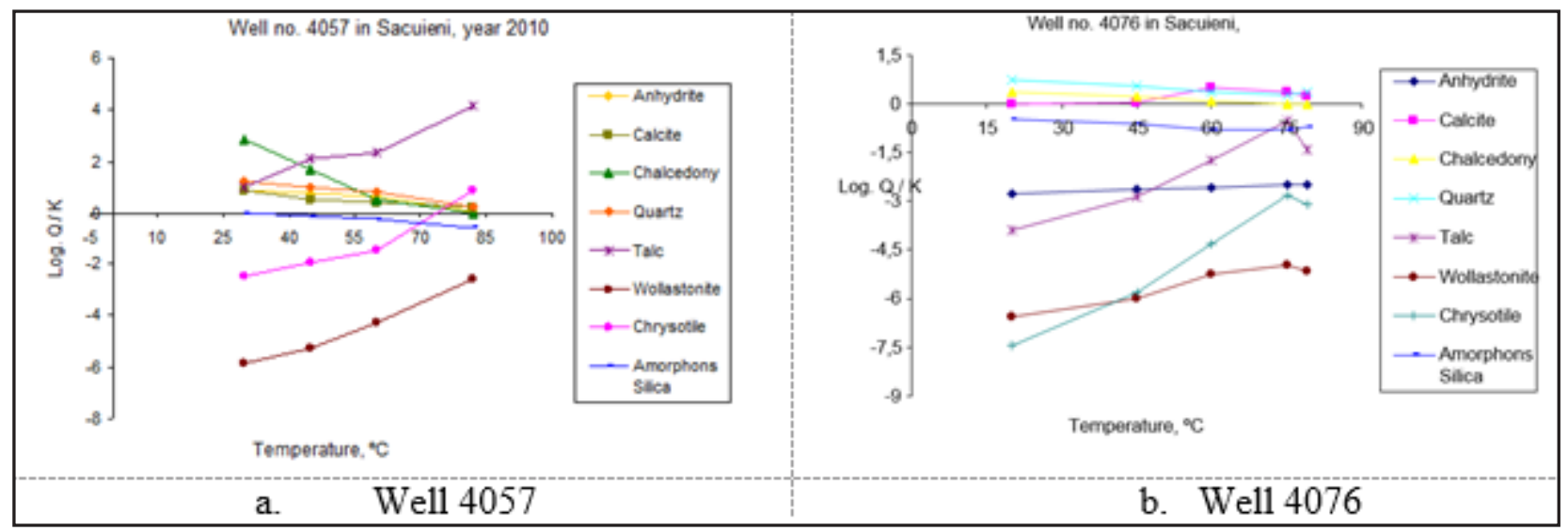

Fig.4. Log.Q/K vs. temperature for water

from well 4076 (Figure 5b) shows an endothermic effect which starts at about $765^{\circ} \mathrm{C}$ and ithas a maximum at $985^{\circ} \mathrm{C}$, the mass loss being $42.88 \%$. These results might indicate a carbonate mineral in the solid samples, the mass losses being $\mathrm{CO}_{2}$

The X-Ray diagrams (Figures $6 a$ and $b$ ) for the solid scales from wells 4076, respectively 4057 indicate the presence of calcite, magnesia and quartz crystals [35]. $X$-ray diffraction spectrometric analysis of the samples in Sãcuieni confirmed that calcium carbonate and magnesium carbonate are the major components of the sample submission and to a lesser extent in the form of quart.

By applying the ternary diagram, it results that the studied waters are sodium bicarbonated, both waters plot close to Arnorsson's equilibrium curve in the $\mathrm{Na}^{+}-\mathrm{K}^{+}$$\mathrm{Mg}^{2+}$ diagram and a little away from Giggenbach's curve, this being an indicator of possible mixing. In the $\mathrm{Cl}_{-}-\mathrm{SO}_{4}^{2-}$
$\mathrm{HCO}_{3}$ - ternary diagram both waters from Sacuieni plot near the corner of $\mathrm{HCO}^{-}$and they are peripheral waters.

Bymonitoring the chemical composition of geothermal systems, the deposit and corrosion problems can be estimated, avoiding their occurrence by taking optimization measures. By Watch simulation program there were evaluated possible mineral deposits by calculation the saturation indexes at the measured temperatures and at lower temperatures which can result during exploitation. The solid samples were structurally analyzed, being confirmed calcium carbonate in the crystalline form of calcite as major component of the sample, magnesia and quartz. Calcite and quartz were evaluated by Watch simulation program. Knowing the structure of deposits will help to establish the optimum conditions of operation in order to prevent encrustation.

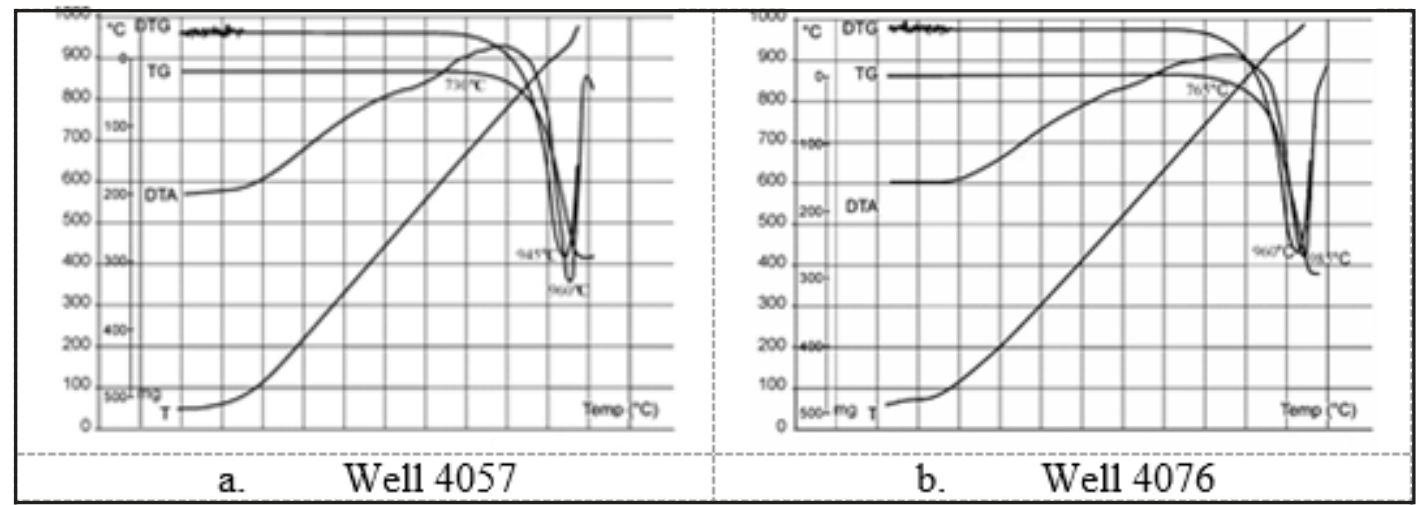

Fig.5. The thermal analytical curves (TG, DTG, DTA, T) of the solid deposits 


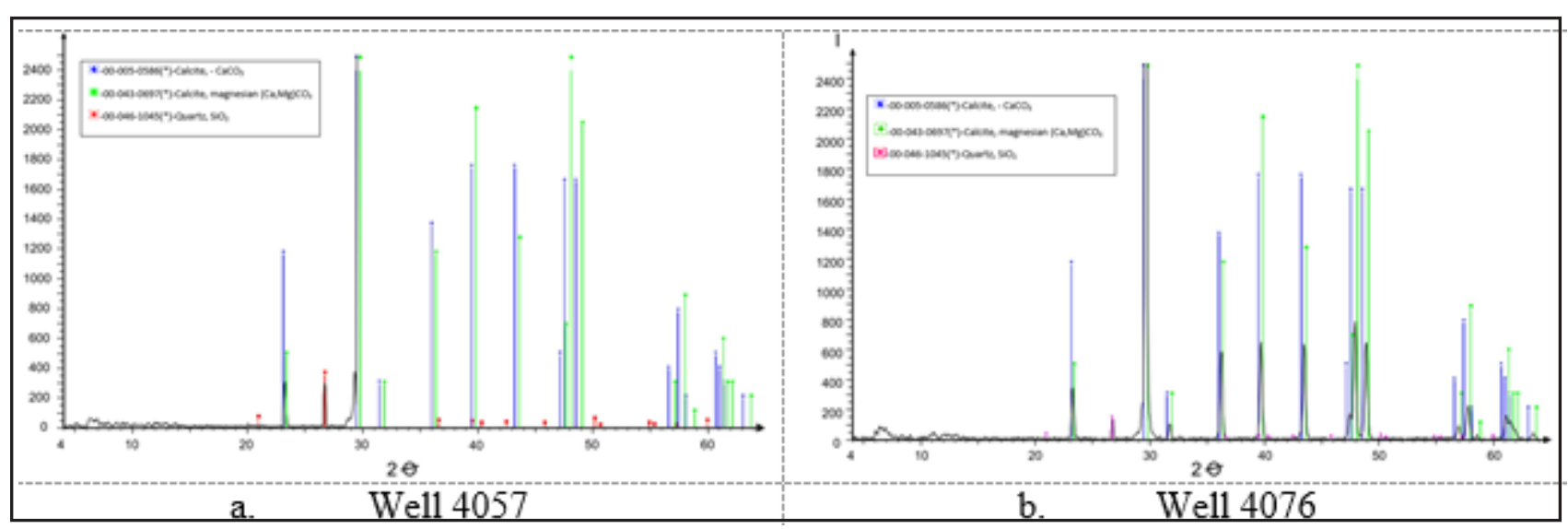

Fig.6. The XRD diagram of the solid deposits

\section{Conclusions}

Geochemical data accuracy depends on the methods used for water sampling and analysing of physical and chemical characteristics of geothermal waters. Laboratory test results were processed and monitored with the help of modeling. The silica geothermometers used to calculate the temperature of geothermal reservoirs gave very close results to the temperatures measured when sampling. The temperatures of the geothermal reservoirs were also established with the silica-enthalpy model. For the two samples in study, there was found that the temperature of geothermal water in the reservoir is higher than the wellhead temperature. This is explained by the mixing with cold water in the upper part or at the contact with rocks.

Our study allows to determine the optimal conditions for an efficient exploitation of these geothermal waters for different industrial and domestic purposes.

\section{References}

1.GIGGENBACH, W.F., Application of geochemistry in geothermal reservoir development, F. D'Amore UNITAR/UNDP publication, Rome, 1991, p. 119.

2.GIGGENBACH W.F., Geochim. Cosmochim. Acta, 52, 1988, p. 2749. 3.ARNORSSON S., Applications of geochemistry in geothermal reservoir development, F. D'Amore UNITAR/UNDP publication, Rome, 1991, p. 145.

4.TRUESDELL A.H., FOURNIER R.O., U.S. Geol. Survey J. Res., 5, 1977, p. 49.

5.FOURNIER R.O., POTTER R.W., Geoth. Res. Council Bull., 11, no.10, 1982, p. 3.

6.PAULIK FERENC, Special Trends in Thermal Analysis, John Wiley \& Sons Ed., 1995.

7.FOLDVARI, M., Handbook of termogravimetric system of minerals and its use in geological practise, Occasional Papers of the Geological Institute of Hungary, Vol. 213, Budapest, 2011.

8.POROWSKI, A., Thermal and Mineral Waters. Origin, Properties and Applications, Springer-Verlag Heidelberg, Berlin,2014.

9.ROLKER, J., SCHILL E., STOBER, I., SCHNEIDER, J., NEUMANN, T., KOHL, T., Geothermal Energy, 3, no. 5, 2015, p. 1.

10.ERSOY, A.F., SONMEZ, S.C., Environ. Earth Sci., 72, 2014, p. 4451. 11.BRAHIM, F.M., MAKNI, J., BOURI, S., DHIA, H.B., Environ. Earth Sci., 69, 2013, p. 2125.

12.WEN, Y., WANG, N.L, HU, Z., Environ. Earth Sci., 67, 2012, p. 1281. 13.CHULLI, B., DAVRAZ, A., MAKNI, J., BEDIR, M., DHIA, H.B., Environ. Earth Sci. 66, 2012, p. 1.
14.ZAHER, M.A., EHARA, S., EL-QADY, G., Arabian J. Geosci., 4, 2011, p. 161.

15.ANDO, J., KAGI, H., INOUE, T., YAMADA, A., YAMAZAKI, D., IRIFUNE, T., Physics Chem. Minerals, 35, no. 5, 2008, p. 249.

16.SIVAPULLAIAH, P.V., SANKARA, G., ALLAM, M.M., Environ. Earth Sci., 60, 2010, p. 1189.

17.POROWSKI, A., DOWGIALLO, J., Environ. Geol. 58, 2009, p.1629. 18PETRINI, R, ITALIANO, F., PONTON, M., SLEJ KO, F.F., AVIANI, U., ZINI, L., Hydrogeol. J., 21, no.6, 2013.

19.SANLIYUKSEL, D., BABA, A., Environ. Earth. Sci., 62, 2011, p. 529. 20.ROSCA M., ANTAL C., BENDEA C., Geothermal Energy in RomaniaCountry update 2005-2009, in: Proceedings World Geothermal Congress, Bali, Indonesia, 2010.

21.SEBESAN, R., BADEA G., SEBESAN, M., HODISAN, S. Proceedings of World Geothermal Congress 2015, Melbourne, Australia, 2015.

22.STANASEL, O.D., KRISTMANNSDOTTIR, H., GAVRIS, G., STANASEL, I., Rev. Chim. (Bucharest), 61, no. 8, 2010, p. 778.

23.SETEL, A., SEBESAN, M., BADEA, G.E., ANTAL, C., SEBESAN, R., Int. Rev. Appl. Sci. Eng, 1, no. 1-2, 2010, p. 31.

24.BADEA, G.E., IONITA, D., CRET, P., Mater. Corros., 65, 2014, p. 1103. 25.BADEA, G.E., BADEA, T., Rev. Roum. Chim, 53, no. 4, 2008, p. 291. 26.BADEA, G.E., MAIOR, I., COJ OCARU A., CORBU I., Rev. Roum. Chim, 52, no. 12, 2007, p. 1123.

27.BADEA, G.E., COJ OCARU, A., BADEA, T., Rev. Chim. (Bucharest), 55, no. 12, 2004, p. 1029.

28.MAIOR, I., BREZOIU, A.M., COJOCARU, A., BADEA, G.E., Proceedings of RICCE, Sibiu, Romania, 2015.

29.COJ OCARU, A., MAIOR, I., VAIREANU, D.I., LINGVAY I., LINGVAY C., CAPRARESCU S., Rev. Chim. (Bucharest), 60, no. 11, 2009, p. 1175. 30.BALINT, R., ORBECI, C., NECHIFOR, G., PLESCA, M., AJMONEMARSAN, F., Rev. Chim.(Bucharest), 64, no.11, 2013, p. 1218.

31.PRADA, M., POPESCU, D.E., BUNGAU, C., PANCU, R., BUNGAU, C, J. Environ. Prot. Ecol., 18, no. 3, 2017, p. 1146.

32.PRADA, M.F., POPESCU, D.E., BUNGAU, C., Building Education, Source of Energy Saving in Romania, in: Proc. of the 15th National Technical-Scientific Conference on Modern Technologies for the 3rd Millennium, Oradea, Romania, 2016, p. 157.

33.VESSELENYI, T., BUNGAU, C., HUSI, G., Research Equipment and Computation Techniques for Intelligent Building Applications, in: Proc. of 2014 IEEE/SICE International Symposium on System Integration. Tokyo, Japan, 2014, p. 228.

34.ARNORSSON, S., BJ ARNASON, J.O., The speciation program WATCH, version 2.3. Orkustofnun, Reykjavik, 2004.

$35{ }^{* * *}$, Mineral Pow der Diffraction File. Data book. International Centre for Diffraction Data 1601 Park Lane. Swarthmore, PA 19081, USA.

$\overline{\text { Manuscript received: } 10.09 .2018}$ 